CURRENT BIBLIOGRAPHY

Recently published works pertaining to sedimentary geology in the Maritime region and environs are listed below. They have been extracted from Geoscience Abstracts, for September, October and November 1965 .

Areal and Regional Geology

CHAMBERLAIN, BARBARA B., 1964, These fragile outposts a a geological look at Cape Cod, Martha's Vineyard, and Nantucket: The Naturai History Press, New York, 327 p。

\title{
Geomorphology
}

FRANCESCHETTI, ALFRED P. 1964, Oceanographic observations: Kennedy Channe1, Kane Basin, Smith Sound and Baffin Bay, summer 1963: U. S. Coast Guard, Oceanog. Rept. No, 5, 98 p.

HARRISON, WYMAN, and KENNETH A, WAGNER, 1964, Beach changes at Virginia Beach, Virginia: U。 So. Army, Corps. Engineers, Coastal Eng, Research Center, Misc. Paper No.6-64, 25 p。

HEIRTZLER, JAMES $R_{\circ}$, and XAVIER LE PICHON, 1965, Crustal structure of the mid-ocean ridges: J. Geophys, Research, v。70, no, 16, p. 4013-4033.

KAYE, CLIFFORD A, 1964, IIlinoian and early Wisconsin moraines of Martha's Vineyard, Massachusetts: U。S. Geoi. Survey, Prof。 Paper 501-C, P. 140-143.

NEWMAN, WALTER $S_{\circ}$, and GENE A。 RUSNAK, 1965, Holocene submergence of the eastern shore of Virginia: Seience, $v_{0} 148$, no. 3676 , p. 1464-1466.

PIERCE, RENNETH L。, 1965, Geomorphic significance of a Cretaceous deposit in the Great Valley of southern Pennsylvania: U.S.Gecl. Survey, ProfoPaper 525-C, p。152-156。

UCHUPI, ELAZAR, 1964, Sediments and topography of Kane Basin Ir: FRANCESCHETTI, ALFRED $P_{\circ}$, and cthers, Oceanagraplic Observaticns: Kennedy Channel, Kane Basin, Smith Sound and Baffin Bay, sumer 1963: U.S. Coast Guard, Oceanog。 Rept, No, 5, P. 61 72.

Structural Geology

ANDERSON, $T_{0} H_{0}$, and others, 1965, Megapetrofabric of the Coatesviileo Doe Run area, Pennsylvania: Pennsylvania Acad. Sei., Proc.s v. 38 , no. 2 , po 174-182。

BRIDGWATER, $D \circ$, and $B$. J.WALTON, 1964, The tectoromagmatis evolution of the svecofennid chelogenic cycie in south Greenland: Greenland Ceo1. Unders $q$ gelse, Misc. Papers No. $44,7 \mathrm{p}$. 
COODE, ALAN M。, 1965, A note on oceanic transcurrent faults: Can. J。 Earth Sci。, v。2, no. 4, p. 400-401。

CREER, K。 Mo, 1965, Some comments on Van Hilten's discussion on ancient continental configurations: Tectonophysics, v。1, no. 6, p. 531535 .

KERR, JoWILLIAM, and Ro. L. CHRISTIE, 1965, Tectonic history of Boothia uplift and Cornwallis fold belt, Arctic Canada: Am. Assoc. Petroleum Geologists, Bu11., v。49, no.7, p. 905-926.

PAVLIDES, LOUIS, and others, 1964, Outline of the stratigraphic and tectonic features of northeastern Maine: U. S. Geo1。 Survey, Prof. Paper 501-C, p. 28-38.

ROCK MECHANICS SYMPOSIUM, QUEEN'S UNIVERSITY, Ottawa, 1964, Proceedings of the rock mechanics symposium held at Queen's University, December 6-7, 1963: $147 \mathrm{p}$ 。

STOCKWELL, C.H。, 1965, Structura1 trends in Canadian Shield: Am. Assoc。 Petroleum Geologists, Bul1, v. 49, no. 7, p. 887-893.

VAN BEMMELEN, $R_{0} W_{0}, 1965$, The evolution of the Atlantic mega-undation (causing the American continental drift): Tectonophysics, $v .1$, no. 5, p. 385-430。

Stratigraphy and Historica1 Geology

CASTLE, R。 0., 1965, Gneissic rocks in the south Groveland Quadrangle, Essex County, Massachusetts: U。 S. Geo1. Survey, Prof. Paper 525-C, p. 81-86.

CURRAY, JOSEPH R。, 1965, Late Quaternary history, continenta1 shelves of the United States: in: WRIGHT, H。E., Jr., and DAVID G。FREY, eds. The Quaternary of the United States....: p. 723-735, Princeton, New Jersey, Princeton University Press.

BELT, EDWARD S。, 1965, Stratigraphy and paleogeography of Mabou Group and related middle Carboniferous facies, Nova Scotia, Canada: Geo1.Soc.America, Bu11., v。76, no. 7, p. 777-801.

DAVIS, MARGARET B., 1965, Phytogeography and palynology of northeastern United States: in: WRIGHT, $H_{0}, E_{0}, J r_{0}$ and DAVID $G_{0}$. FREY, eds. The Quaternary of the United States....: p. 377-401, Princeton, New Jersey, Princeton University Press.

GRIFFIN, JAMES B。, 1965, Late Quaternary prehistory in the northeastern woodlands: in: WRIGHT, H. E。, Jr., and DAVID G。 FREY, eds. The Quaternary of the United States....: p. 655-667, Princeton, New Jersey, Princeton University Press。

KAYE, CLIFFORD A., 1964, Outline of Pleistocene geology of Martha's Vineyard, Massachusetts: U。S。Geol. Survey, Prof。Paper 501-C, p. 134-139. 
MCCOLLUM, MORRIS J., and STEPHEN M。 HERRICK, 1964, Offshore extension of the Upper Eocene to Recent stratigraphic sequence in southeastern Georgia: U.S. Survey, Prof. Paper 501-C, p. 61-63.

MILLER, ROBERT RUSH, 1965, Quaternary freshwater fishes of North America: in: WRIGHT, H。E。, Jr., and DAVID G。FREY, eds. The Quaternary of the United States....: p. 569-581, Princeton, New Jersey, Princeton University Press.

SCHAFER, J。P。 and JOSEPH H. HARTSHORN, 1965, The Quaternary of New England: in: WRIGHT, $H_{0} E_{0}, \mathrm{Jr}$, and DAVID G。FREY, eds. The Quaternary of the United States....: p. 113-128, Princeton, New Jersey, Princeton University Press.

SCHENK, PAUL E。, 1965, Precambrian glaciated surface beneath the Gowganda Formation, Lake Timagami, Ontario: Science, v。149, no.3680, p. 176-177.

TESMER, IRVING H., 1963, Geology of Chautaugua County, New York. Part I: Stratigraphy and paleontology (Upper Devonian): New York, State Mus。\& Sci. Service, Bul1。No.391, 65 p。

TOZER, E. T., 1965, Lower Triassic stages and ammonoid zones of Arctic Canada: Canada, Geo1。 Survey, Paper 65-12, $14 \mathrm{p}$.

TSCHUDY, ROBERT H., 1965, An Upper Cretaceous deposit in the Appalachian mountains: U。 S. Geo1. Survey, Prof. Paper 525-B, p. 64-68.

\section{$\underline{\text { Paleontology }}$}

BUZAS, MARTIN A。, 1965, The distribution and abundance of foraminifera in Lond Island Sound: Smithsonian Inst., Smithsonian Misc. Contr., $\mathrm{v} .149$, no. $1,89 \mathrm{p}$.

KINDLE, CECIL H。, and HARRY B. WHITTINGTON, 1965, New Cambrian and Ordovician fossil localities in western Newfoundland: Geol. Soc. America, Bu11., v。 76, no.6, p。683-687.

KOENIG, JOHN W。, and DAVID L。 MEYER, 1965, Two new crinoids from the Devonian of New York: J。Paleontology, v。39, no. 3, P.391-397.

LERMAN, ABRAHAM, 1965, Evolution of Exogyra in the late Cretaceous of the southeastern United States: J. Paleontology, v. 39, no. 3, p. 414-435.

RICHARDS, HORACE $G_{0}$, and EARL A. SHAPIRO, An invertebrate macrofauna from the Upper Cretaceous of Delaware: Delaware, Geol. Survey, Rept. Inv. No。7, $37 \mathrm{p}$ 。

ROGERS, MARGARET JENNIFER, 1965, A revision of the species of nonmarine bivalvia from the Upper Carboniferous of eastern North America:

J. Paleontology, v。39, no. 4, p. 663-686.

SCHOPF, JAMES M。, 1964, Middle Devonian plant fossils from northern Maine: U. S. Geol. Survey, Prof. Paper 501-D, p. 43-49. 
WHITTINGTON, HARRY $B_{\circ}, 1965$, Trilobites of the Ordovician Table Head formation, western Newfoundland: Harvard Univ., Mus. Comp. Zoology, Bu11。, v。132, no.4, p。275-442。

\section{Geophysics}

AVERY, OTIS E。, 1963, Geomagnetic and bathymetric profiles across the North Atlantic Ocean: U。 S. Naval Oceanog. Office, Tech. Rept。TR-161, $74 \mathrm{p}$.

BECK, M。. E。, Jr。, 1965, Paleomagnetic and geological implications of magnetic properties of the Triassic diabase of southeastern Pennsylvania: J。Geophys。Research, v. 70, no. 12, p.2845-2856.

BERGER, J.o, and others, 1965, Geophysical observations on sediments and basement structure underlying Sable Island, Nova Scotia: Am. Assoc. Petroleum Geologists, Bu11, v。49, no。7, p。959-965.

HODGSON, JOHN H., 1965, Canadian earthquakes: Can. Geog。 J。, v. 71, no. $1, p$ 。30-39.

LAW, L. K., and others, 1965, Heat flow determinations in the Canadian Arctic Archipelago: Ottawa, Dominion Observatory, Contr., v. 6, no. 14,13 p。; reprinted from: Can. J. Earth Sci。, v。 2, no.2, p.59-71。

LE PICHON, XAVIER, and MANIK TALWANI, 1964, Gravity survey of a seamount near $35^{\circ} \mathrm{N} 46^{\circ} \mathrm{W}$ in the North Atlantic: Marine Geology, v. 2, no. 4, p. $262-277$.

VAN VOORHIS, GERAĹD D。 and JAMES E. WALCZAK, 1963, Summary of magnetization computations for Kelvin seamount. Preliminary Report: U. S. Nava1 Oceanog. Office, Informal Ms。Rept。No。 M-8-63, 19 p。

Sedimentary Petrology

BISCAYE, PIERRE E., 1965, Mineralogy and sedimentation of recent deepsea clay in the Atlantic Ocean and adjacent seas and oceans:

Geo1.Soc. America, Bu11。, v.76, no.7, p.803-831.

FERM, JOHN C。, and EUGENE G. WILLIAMS, 1965, Characteristics of a Carboniferous marine invasion in western Pennsylvania: J. Sed. Petrology, v。35, no. $2, \mathrm{p} .319-330$ 。

HANSEN, KAJ, 1964, Lagoon sediments in Greenland: in: STRAATEN, L。M,J。U。 VAN, ed. Deltaic and shallow marine deposits...: p. 165-169. New York, American Elsevier Publishing Co.

KLEIN, GEORGE DeVRIES, 1964, Sedimentary facies in Bay of Fundy intertidal zone, Nova Scotia, Canada: in: STRAATEN $L_{0} L_{\circ} M_{\circ} J_{\circ} U_{\circ}$ VAN, ed. Deltaic and shallow marine deposits...: p。193-199, New York, American Elsevier Publishing Co.

MIDDLETON, $G 。 V_{0.8} 1965$, Paleocurrents in Normanskill graywackes north of Albany, New York: Geo1.Soc。America, Bul1, v。76, no.7,

p. 841-843. 
RYAN, J. DONALD, 1965, Cross-bedding formed by lateral accretion in the Catskill formation near Jim Thorpe, Pennsylvania: Pennsylvania Acad.Sci., Proc., v。38, no.2, p。154-156.

SCHENK, PAUL E., 1965, Depositional environment of the Gowganda Formation (Precambrian) at the south end of Lake Timagami, Ontario: J.Sed.Petrology, v。35, no. 2, p. 309-318.

SCHLEE, JOHN S., and others, 1964, Statistical parameters of Cape Cod beach and eolian sands: U。S. Geo1。Survey, Prof。 Paper 501-D, p. $118-122$.

SCHOLL, DAVID $W_{0}, 1964$, Recent sedimentary record in mangrove swamps and rise in sea level over the southwestern coast of Florida: Part 2: Marine Geology, v。2, no。4, p。343-364.

\section{Groundwater}

BAKER, JOHN A。, and others, 1965, Geology and hydrology of the Hartford research center canel site, Middletown, Connecticut: U。 S. Geol. Survey, Bull. 1133-G, 42 p。

HECK, E。 T。, and others, 1964, Appalachian connate water: West Virginia, Geo1。Survey, Bu11。28, $42 \mathrm{p}$.

PERLMUTTER, NATHANIEL $M_{0}$, and others, 1964, Contamination of groundwater by detergents in a suburban environment Long Island, New York: U. S. Geo1. Survey, Prof. Paper 501-C, p. 170-175.

SEABER, PAUL $R_{0}, 1965$, Variations in chemical character of water in the Englishtown Formation, New Jersey: U. S。 Geo1. Survey, Prof. Paper $498-\mathrm{B}, 35 \mathrm{p}$.

\section{Mineral and Fue1 Deposits}

CANNEY, F。C。, and EDWIN V。POST, 1964, Suggested exploration target in west-centra1 Maine: U. S。 Geo1. Survey, Prof. Paper 501-D, p.61-64.

EMERY, K。 O., 1965, Some potential mineral resources of the Atlantic continenta1 margin: $U$. S。Geo1。 Survey, Prof. Paper 525-C, p。157-160。

GROSS, G。 A., 1965, Geology of iron deposits in Canada. Volume 1: General geology and evaluation of iron deposits. With a statistical summary of the Canadian iron ore industry and world iron ore markets, by $T_{\circ} \cdot H_{0}$ JANES: Canada, Geol. Survey, Econ。 Geology Rept. No。22, $181 \mathrm{p}$.

JOHNSTON, A。G.o, and W. DOUGLAS McCARTNEY, 1965; Manganese occurences (sic) in Canada (preliminary reports and metallogenic map): Canada, Geol. Survey, Paper 64-37, 63 p。

McKILLOP, JOHN H., 1965, Industrial minerals in Newfoundland: Can. Mining \& Metall。Bull, v。58, no.639, p。746-755。 
MILNE, J.E. $\mathrm{S}_{\circ}$, and $\mathrm{R}_{\circ} \mathrm{D}_{\circ}$ HOWIE, 1965, Developments in eastern Canada in 1964: Am. Assoc. Petroleum Geologists, Bu11., v. 49, no.6, p. 841-853.

RICHARDS, HORACE G。, 1965, Developments in Atlantic coastal states north of Carolina in 1964: Am. Assoc. Petroleum Geologists, Bu11., v. 49, no. $6, \mathrm{p}$ 。684-685.

Igneous and Metamorphic Petrology

CHAPMAN, RANDOLPH $W_{0}, 1965$, Stratigraphy and petrology of the Hampden Basalt in central Connecticut: Connecticut, Geo1。\& Nat. History Survey, Rept. Inv. No. 3,38 .

ENGEL, ALBERT E. J.o, and others, 1965, Chemical characteristics of oceanic basalts and the upper mantle: Geol. Soc. America, Bull., v. 76, no. 7, p.719-734.

Miscellaneous

HENDERSON, J。R., comp., 1965, Canadian university graduate theses in the geological sciences: Canada, Geol. Survey, Paper 64-46, 71 p.

WRIGHT, J。R. comp., 1965, Index to reports of Geological Survey of Canada from 1951-59: Ottawa, Geological Survey of Canada, 379 p.

Recent Publications in Marine Geology from Bedford Institute of Oceanography

Reports

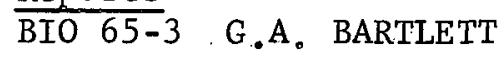

BIO 65-6 R.J. LESLIE

BIO 65-9 A。C。GRANT

BIO 65-10 R。G。PIRIE

BIO 65-12 R。J 。 LESLIE

$B$.R. PELLETIER

BIO 65-13 G.A. BARTLETT

BIO 65-14 L。H。KING

BIO 65-15 J.I.MARLOWE
Preliminary investigation of benthonic foraminiferal ecology in Tracadie Bay, Prince Edward Island.

Ecology and paleoecology of Hudson Bay foraminifera.

Distributional trends in the Recent marine sediments of Northern Baffin Bay.

Petrology and physica1 chemical environment of bottom sediments of the Rivieré Bonaventure - Chaleur Bay area, Quebec, Canada.

Bedrock geology beneath Hudson Bay as interpreted from submarine physiography。

Preliminary notes on Recent species of Elphidiidae in shallow waters of the Atlantic provinces of Canada.

Use of a conventional echo sounder and textural analyses in delineating sedimentary facies - Scotian Shelf.

Sedimentology of the Prince Gustaf Adolf Sea area, District of Franklin. 
Outside Publications

Contribution

No.

Marine geology in Arctic Canada and Hudson Bay: in Encyclopedia of Earth Sciences: ed $R_{0} W_{0}$. Fairbridge (in press).

B.R. PELLETIERI Development of submarine physiography in the Arctic Archipelago and its relation to crustal movements: Roy. Soc. Canada (in press); also BIO Report 64-16.

32 J.I. MARLOWE

Probable Tertiary rocks from a submarine canyon off Nova Scotia: Marine Geology, $v_{0} 3$, no. 4., p. 263-268.

Foraminifera distribution in Tracadie Bay, Prince Edward Island: Geol. Surv. Canada Paper (in press). current fluctuations in Baffin Bay: Canadian J. Earth Sci., (in press). 